\title{
EMBRITTLEMENT OF MALLEABLE CAST IRON RESULTING FROM HEAT TREATMENT.
}

\author{
By Leslie H. Marshall. ${ }^{1}$
}

ABSTRACT.

The investigation detailed in this paper has shown that commercial malleable cast iron is embrittled to a greater or lesser degree, depending on the iron, by quenching from certain temperatures in the "blue-heat" range, such as are obtained in the hotdip galvanizing process. This drop in impact resistance is lessened by slow cooling, but is not affected by subsequent aging. The fundamental cause of this behavior is not yet known. The embrittlement can be eliminated, however, by heating to $650^{\circ} \mathrm{C} .\left(1,200^{\circ} \mathrm{F}\right.$. $)$ for a few minutes.

\section{CONTENTS.}

I. Introduction. $\ldots \ldots \ldots \ldots \ldots \ldots \ldots \ldots \ldots \ldots \ldots \ldots \ldots \ldots \ldots \ldots \ldots$

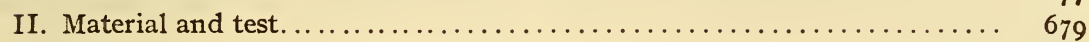

III. Treatment in the "blue-heat" range...................... 680

I. Embrittlement and heat treatment................. 680

2. Rate of heating. .................................. $68 \mathrm{r}$

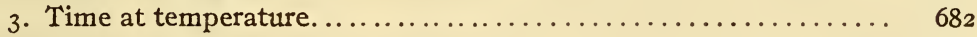

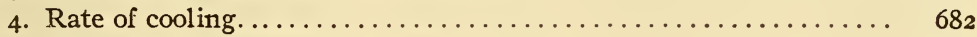

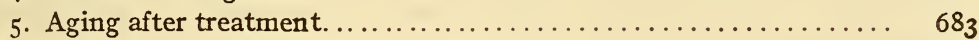

IV. Effect of varying the quenching temperature $\ldots \ldots \ldots \ldots \ldots \ldots \ldots \ldots \ldots 68$

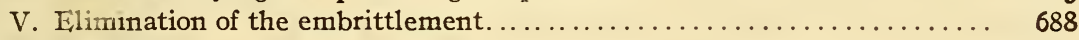

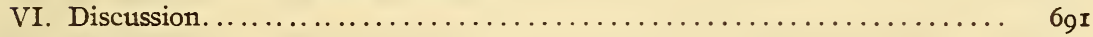

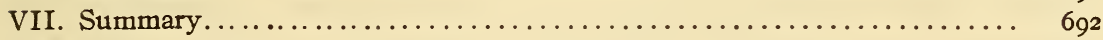

\section{INTRODUCTION.}

The question of brittleness in ferrous alloys has attracted considerable attention of late. This consideration is but a natural result of the considerable amount of trouble for which this fault is responsible. In fact, in one or more of its guises, it confronts each member of the engineering profession. One recognized phase of the problem that is of great practical importance is the phenomenon of brittleness in the blue-heat range. Such weakness in iron and low-carbon steel has been known for some time, but the consequences of this baneful tendency have not all been enumerated.

${ }^{1}$ Metallurgist, Ohio Brass Co., Mansfield, Ohio. 
A pertinent consideration in this connection may be found in the embrittlement of malleable iron in hot-dip galvanizing.

It is now well recognized that malleable iron sometimes deteriorates appreciably when treated in the hot-dip process. Numerous references in the literature ${ }^{2}$ give evidence of this fact and put forward many theories to explain such behavior. Positive data on the subject were practically nonexistent when the present investigation was started. Since that time, however, Bean ${ }^{3}$ has published specific information on the problem of embrittlement in galvanizing and has pointed out the important rôle played by the phosphorus content of the metal. The results presented herewith are the findings of an independent investigation of the same problem attacked from a somewhat different viewpoint.

It is interesting to note that Bean's results check with those obtained in the present experiments in showing that the embrittlement of the iron is due to the heat treatment incidental to the galvanizing process and is largely independent of any other factor of the hot-dip treatment. Thus the malleable iron may be heated in air, salt, or lead bath and the same results obtained as with a zinc bath.

This point may be made clearer by giving more details. The hot-dip galvanizing process consists essentially of immersing the castings to be coated in molten zinc at $440-480^{\circ} \mathrm{C}$. $\left(825-900^{\circ} \mathrm{F}\right.$.). The pieces remain in this bath a minute or more, or until they have reached the temperature of the zinc. They are then removed and quickly cooled, usually by quenching in hot water. At the outset of this work it was found that the embrittlement caused by the hot-dip process could be duplicated by simply heating the malleable iron to the galvanizing temperature in any medium and then quenching.

It was evident, therefore, that important heat-treatment effects are produced in malleable iron in the blue-heat range; that is, about $300-500^{\circ} \mathrm{C}$. $\left(570-930^{\circ} \mathrm{F}\right.$.). Such a finding was naturally an invitation to investigate the field. The interest in the problem was enhanced by the possible connection between this marked deterioration in malleable iron and the more widely known "blue brittleness" of low-carbon steel. Since this field of heat treatment was comparatively untouched for malleable iron only a few phases of the situation were covered and are described below.

\footnotetext{
${ }^{2}$ Bean, Highriter, and Davenport, Foundry, 49 (I92I), p. 557; Schwartz, Iron Trade Rev., 69 (I92I), p. 6I7: Touceda, Trans. Am. Soc. Mech. Eng., 41 (I92I), p. 9 I.

${ }^{3}$ Min. and Met.o 4 (I923), p. 86.
} 


\section{MATERIAL AND TEST.}

Most of the data recorded in this paper were obtained on samples cut from a single slab of well-graphitized malleable iron. The composition of this metal, as determined by analysis of the annealed samples, was as follows: Total carbon 2.10, graphitic carbon 2.00 , silicon 0.80 , phosphorus 0.20 , manganese 0.26 , and sulphur 0.073 per cent. In each case the outside skin of partly decarburized metal was machined off the test specimens. This procedure did, it is true, differentiate the experimental iron from that found in practice, where the outer skin adds somewhat to the strength of the casting. The decarburized zone varied in depth, however, so its elimination seemed imperative if consistent results were to be obtained.

Having secured the malleable iron with which to carry on the investigation it became necessary to choose a test for measuring the brittleness of the material, since this quality was the one that varied most widely. Brittleness is a somewhat indefinite term, however, that is difficult either to define or measure accurately. Nevertheless, malleable castings that have become brittle often evidence their poor quality in practice by readily fracturing under a sharp blow. Such behavior suggested the use of the impact test. The Izod type was chosen for this work. Figure I

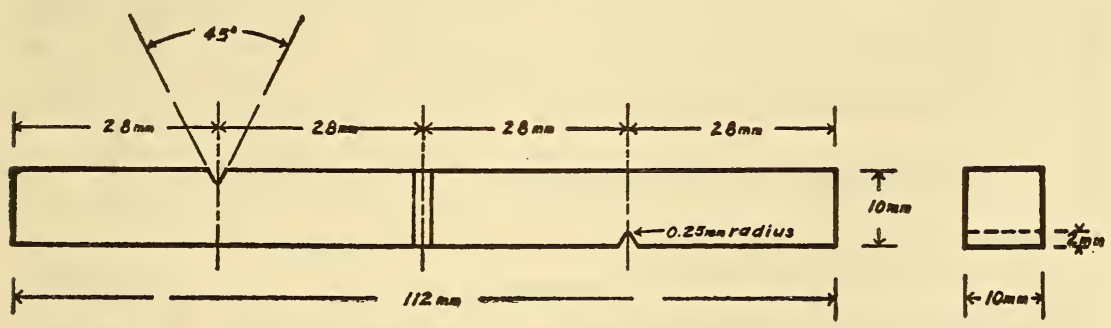

Fig. I.-Impact specimen used.

shows the type of specimen employed. Each specimen had three notches, as illustrated; thus three impact results were obtained on every sample. The machine and manipulation were normal for this type of test, ${ }^{4}$ the specimen being clamped at one end and struck near the free end by a swinging tup. By the use of a template the center of the notch was located exactly on a level with the top of the vise each time. This impact test gave quick,

\footnotetext{
'For description of test see Lessells, Trans. Am. Soc. Steel Treat, 2, p. 659; 1922.
} 
consistent results, and since malleable iron has relatively low ductility no difficulty was encountered from the metal failing to fracture under the blow.

\section{TREATMENT IN THE BLUE-HEAT RANGE.}

\section{EMBRITTLEMENT AND HEAT TREATMENT.}

Several theories have been advanced to account for the marked deterioration encountered in hot-dip galvanizing, but, as mentioned above, it soon became evident that the embrittlement resulted from the heat treatment involved. Table I presents data to support this conclusion. The treatment in this case and throughout the investigation was standardized in that the specimens were immersed in the molten bath at the desired temperature and held there three minutes, whereupon they were removed and quickly quenched in water at $80 \pm 5^{\circ} \mathrm{C}$. (I $75 \pm 9^{\circ} \mathrm{F}$.). Unless otherwise specified, a bath of about roo pounds of molten lead was used in heating the specimens.

TABLE 1.-Comparati ve Effects of Heat Treatment and Galvanizing on the Brittleness of Malleable Iron.

$\begin{gathered}\text { Specimen } \\ \text { number. }\end{gathered} \mid$ Treatment. $\ldots$

As compared with the untreated material.

This table indicates the satisfactory manner in which the impact values of similar material treated in the same way checked. The value given for each specimen is the average of three results, since the specimen had three notches. The figures presented show plainly enough that both the galvanizing and the heat treatment reduced the impact resistance of the metal in a radical fashion. There was also a decided contrast in the appearance of the fractures of the untreated and the quenched specimens. The former possessed the usual dark color characteristics of well-annealed malleable iron. After heating and quenching, however, the fracture was very light silvery gray in color. 
The similarity in the effects of the galvanizing and heat treatment is noteworthy, the seriousness of the deterioration in either case being attested by the drop to about one-tenth of the original impact resistance.

These specimens, as well as all the others used in this investigation, were machined to size and notched before treatment. In order to make sure that this procedure was not giving misleading results by introducing localized stress effects, several samples were treated and then machined. Others were treated and tested without notching. In every case the data obtained indicated a decided embrittlement of the metal itself.

The embrittling effect of hot-dip galvanizing having been shown to result from heat treatment, a closer study was made of the conditions under which this marked deterioration took place. An investigation was consequently made of the following four factors: (I) Rate of heating, (2) time at temperature, (3) rate of cooling, and (4) aging after treatment. The temperature of heat treatment was $460 \pm 5^{\circ} \mathrm{C}$. $\left(860 \pm 9^{\circ} \mathrm{F}\right.$.), in each case, a calibrated copper-constantan thermocouple being employed for the measurement of the temperature.

\section{RATE OF HEATING.}

In determining the effect of the rate of heating on the impact resistance of the iron the other variables were, of course, eliminated as far as possible. The time at temperature was three minutes and the cooling rate standardized by quenching in hot water.

TABLE 2.-Effect of the Rate of Heating Upon the Resulting Brittleness.

\begin{tabular}{|c|c|c|c|}
\hline \multirow{2}{*}{$\begin{array}{l}\text { Specimen } \\
\text { number. }\end{array}$} & \multirow[b]{2}{*}{ Treatment. } & \multicolumn{2}{|c|}{ Mean impact value. } \\
\hline & & $\begin{array}{c}\text { Energy } \\
\text { absorbed. }\end{array}$ & $\begin{array}{l}\text { Relative } \\
\text { value. }{ }^{1}\end{array}$ \\
\hline 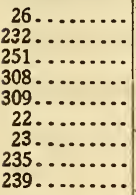 & 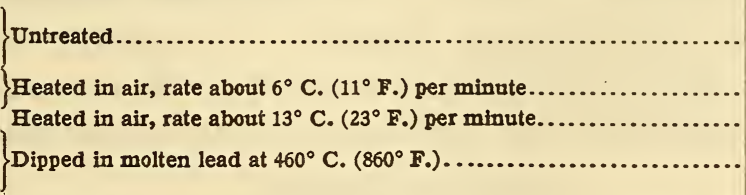 & $\begin{array}{r}\text { Ft. }- \text { lbs. } \\
7.2 \\
.8 \\
1.0 \\
.8\end{array}$ & $\begin{array}{r}\text { Per cent. } \\
100 \\
11 \\
14\end{array}$ \\
\hline
\end{tabular}

${ }^{1}$ As compared with the untreated metal.

Table 2 shows the data obtained by varying the heating rate from $6^{\circ} \mathrm{C}$. ( $\left(\mathrm{II}^{\circ} \mathrm{F}\right.$.) to more than $100^{\circ} \mathrm{C}$. ( $\left(80^{\circ} \mathrm{F}\right.$.) a minute. The results on the untreated metal are included for comparison. 
It is evident that within the range studied changes in the rate of heating produced no marked effect on the impact resistance of the iron.

3. TIME AT TEMPERATURE.

TABLE 3.-Variation of Impact Value with the Heating Period.

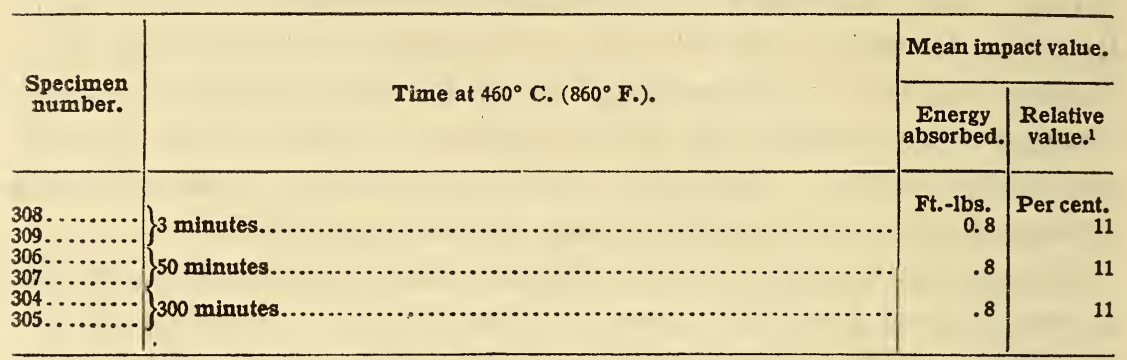

1 As compared with the untreated metal.

The second factor, that of varying the time during which the samples were held at temperature, was investigated by heating in air simultaneously the six specimens listed in Table 3 . The furnace was first brought to temperature, then all the samples were introduced at one time. After the pieces had reached the desired temperature the heating was continued for three minutes. Two of them were then removed and quenched in water at $80^{\circ}$ C. $\left(176^{\circ} \mathrm{F}\right.$.). The remaining four were maintained at temperature for 47 minutes more, when another pair was quenched in the same way. The two that still remained were quenched after a total of 300 minutes at temperature. The variations from $460^{\circ} \mathrm{C}$. $\left(860^{\circ} \mathrm{F}\right.$.) were within $\pm 5^{\circ} \mathrm{C}$. $\left(9^{\circ} \mathrm{F}\right.$.) in these experiments.

The values listed show that the resulting impact resistance was the same in each case. Shorter heating periods were not investigated because they were thought to be too short to permit the entire specimen to reach the desired temperature. A sample dipped in lead at $460^{\circ} \mathrm{C}$. $\left(860^{\circ} \mathrm{F}\right.$.) for 30 seconds suffered practically the same embrittlement, however. It appears, therefore, that the time this particular metal was held at the above temperature could vary within wide limits and yet not affect the results.

\section{RATE OF COOLING.}

In studying the rate of cooling the same general conditions obtained as in the preceding experiments. The heating rate was maintained uniform by treating the specimens in molten lead, except Nos. 27 and $3 \mathrm{I}$, which were heated in air. The time at temperature was three minutes in each case. 
TABLE 4.-Variation of Impact Value with Cooling Rate.

\begin{tabular}{|c|c|c|c|}
\hline \multirow{2}{*}{$\begin{array}{l}\text { Specimen } \\
\text { number. }\end{array}$} & \multirow[b]{2}{*}{ Treatment. } & \multicolumn{2}{|c|}{ Mean impact value. } \\
\hline & & $\begin{array}{c}\text { Energy } \\
\text { absorbed. }\end{array}$ & $\begin{array}{l}\text { Relative } \\
\text { value. }{ }^{1}\end{array}$ \\
\hline & & Ft. -lbs. & Per cent. \\
\hline & Quenched in water at $0^{\circ}$ C. $\left(32^{\circ} \mathrm{F}.\right)$... & 0.5 & \\
\hline & Quenched in water at $80^{\circ} \mathrm{C} .\left(176^{\circ} \mathrm{F}.\right) \ldots$ & .8 & 11 \\
\hline & 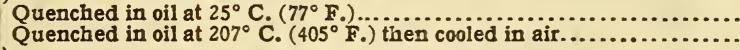 & .7 & $\begin{array}{l}10 \\
24\end{array}$ \\
\hline & 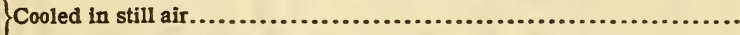 & 3.4 & 47 \\
\hline $\begin{array}{l}24 \ldots \ldots \cdots \\
27 \ldots \ldots \cdots \\
31 \ldots \ldots \cdots\end{array}$ & 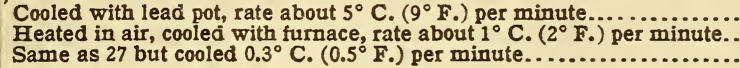 & $\begin{array}{l}2.4 \\
5.4 \\
5.1\end{array}$ & $\begin{array}{l}33 \\
75 \\
71\end{array}$ \\
\hline
\end{tabular}

${ }^{1}$ As compared with the untreated metal.

Table 4 lists the results obtained in studying the cooling rate. Quenching in water made the iron very brittle. Cold water appeared to be somewhat more effective than hot in this respect. The same is true of oil quenching. Air cooling caused less harm. A further small decrease in the rate of cooling, specimen 24, did not cause a proportionate rise in impact resistance. Very slow rates, specimens 27 and $3 \mathrm{I}$, however, rendered the metal much more resistant to impact. These results fall into line quite well and show plainly that the slower the metal cooled the higher the impact value. The rate of cooling is, therefore, a factor of decided importance.

\section{AGING AFTER TREATMENT.}

Having thus shown that quenching from $460^{\circ} \mathrm{C}$. $\left(860^{\circ} \mathrm{F}\right.$.) yielded consistently brittle metal, the question arose as to the permanency of this effect. Several specimens were embrittled by the above procedure and then tested after storage in a desiccator at room temperature for various periods. The results showed that aging for periods up to four months caused no decrease in the embrittlement.

The effect of repeated quenching from this blue-heat temperature was also touched upon. It was found, however, that the first quench caused the embrittlement, subsequent quenching having little influence on the results.

This evidence on the effect of various treatments at $460^{\circ} \mathrm{C}$. $\left(860^{\circ} \mathrm{F}\right.$.) may be summarized by noting that the malleable iron investigated could be heated to that temperature, either slowly or rapidly, and held there for a long or a short time without $61317^{\circ}-23-2$ 


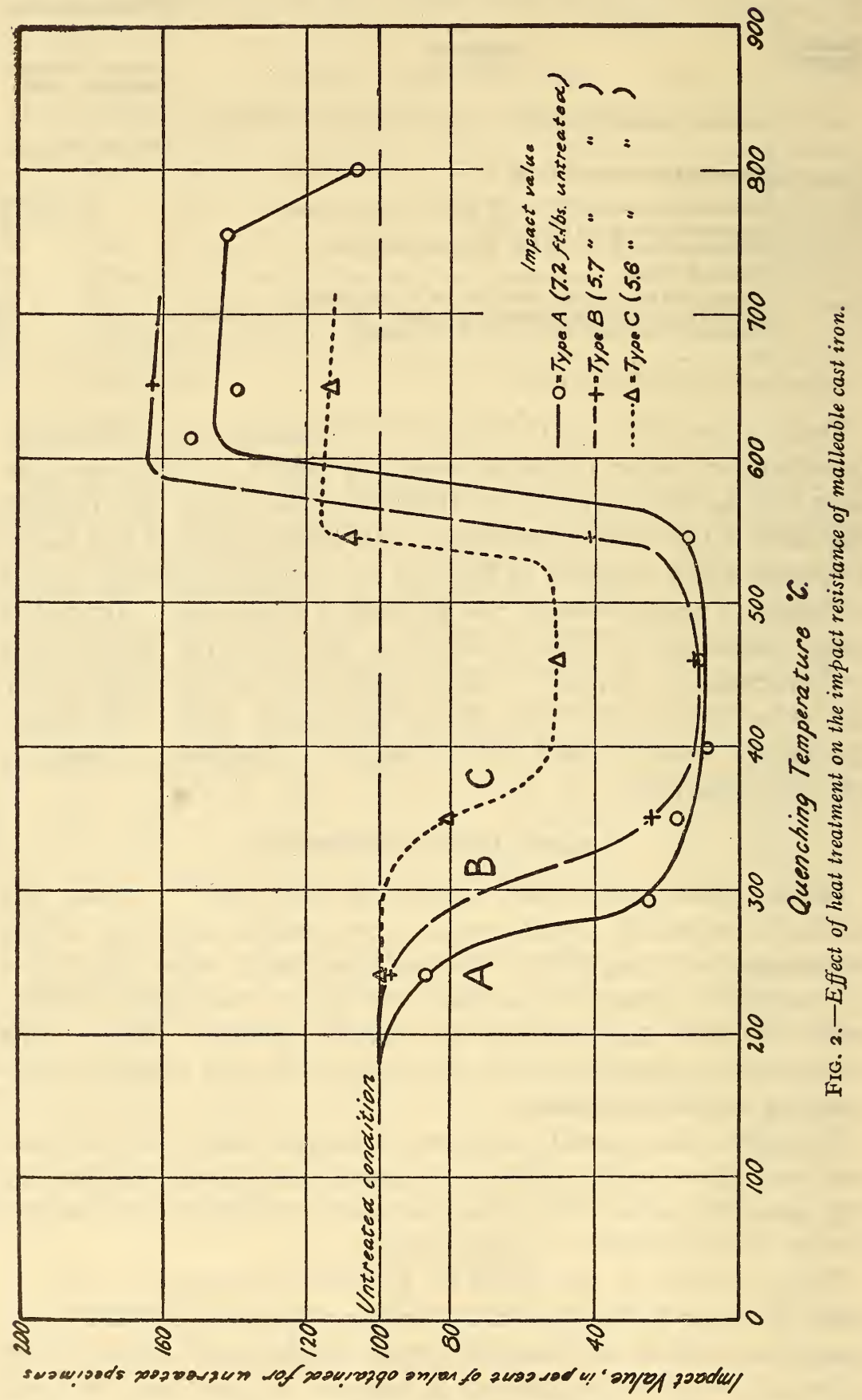


varying the embrittlement that resulted from subsequent quenching in hot water. The rate of cooling from the elevated temperature was important, however, for the slower the cooling the more resistant to impact the metal became.

\section{EFFECT OF VARYING THE QUENCHING TEMPERATURE.}

So far all the results had been obtained with heat treatments at $460^{\circ} \mathrm{C}$. $\left(860^{\circ} \mathrm{F}\right.$.). With the effects of this temperature fairly well surveyed, the next step was to investigate the influence of variations in the quenching temperature. The effect of variables other than the one under consideration were minimized by using a similar method of heat treatment each time. The procedure consisted in immersing the specimens in a bath at the desired temperature, holding them there three minutes, and then quenching in hot water. An oil bath and mercury thermometer were used up to $300^{\circ} \mathrm{C}$. $\left(572^{\circ} \mathrm{F}\right.$.) and a lead bath for higher temperatures. Calibrated thermocouples, copper-constantan to $500{ }^{\circ} \mathrm{C}$. (932 ${ }^{\circ} \mathrm{F}$.) and chromel-alumel beyond that temperature were used with the lead bath. The recorded temperatures are within $\pm 5^{\circ} \mathrm{C}$. $\left(9^{\circ} \mathrm{F}\right.$.) of the true value. The variation of impact value with quenching temperature is shown in Table 5. The same data are presented graphically in curve $A$ of Figure 2.

TABLE 5.-Variation of Impact Value with Quenching Temperature.

\begin{tabular}{|c|c|c|c|c|}
\hline \multirow{2}{*}{ Specimen number. } & \multirow{2}{*}{\multicolumn{2}{|c|}{ Quenching temperature. }} & \multicolumn{2}{|c|}{ Mean impact value. } \\
\hline & & & $\begin{array}{c}\text { Energy } \\
\text { absorbed. }\end{array}$ & $\begin{array}{c}\text { Relative } \\
\text { value.l }\end{array}$ \\
\hline 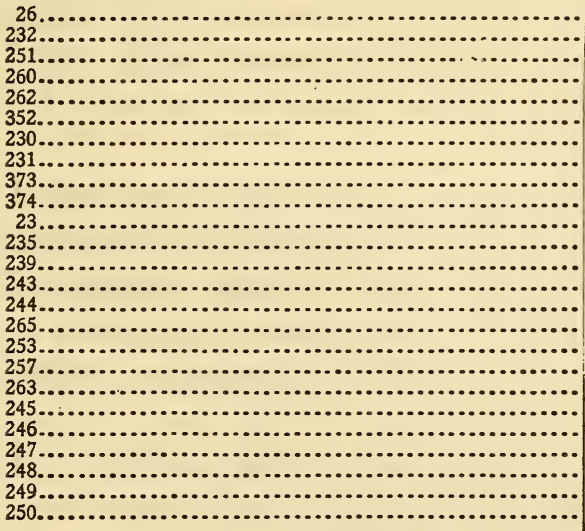 & $\left\{\begin{array}{r|}{ }^{\circ} \mathrm{C} \\
\text { Untreated } \\
240 \\
293 \\
350 \\
400 \\
460 \\
545 \\
577 \\
613 \\
647 \\
754 \\
800\end{array}\right\}$ & \begin{tabular}{r}
\multicolumn{1}{c}{${ }^{\circ}$ F. } \\
Untreated. \\
464 \\
560 \\
662 \\
752 \\
860 \\
1,013 \\
1,070 \\
1,135
\end{tabular} & $\begin{array}{r}\text { Ft.-lbs. } \\
7.2 \\
\\
6.3 \\
1.8 \\
1.2 \\
.6\end{array}$ & $\begin{array}{r}\text { Per cent. } \\
100 \\
87 \\
25 \\
17 \\
9 \\
11 \\
14 \\
63\end{array}$ \\
\hline
\end{tabular}

1 As compared with the untreated metal. 
The data for the range of quenching temperatures studied may be divided into five divisions. In the first, $200-375^{\circ} \mathrm{C}$. $\left(390-710^{\circ}\right.$ F.), the impact value dropped rapidly. The second, $375-550^{\circ} \mathrm{C}$. (7 $\left.10-1,020^{\circ} \mathrm{F}.\right)$, covered the period of greatest embrittlement. The third, $550-610^{\circ} \mathrm{C}$. $\left(\mathrm{I}, 020-\mathrm{I}, \mathrm{I} 30^{\circ} \mathrm{F}\right.$.), again evidenced a very marked increase in impact resistance. The fourth, $610-760^{\circ} \mathrm{C}$. $\left(\mathrm{I}, \mathrm{I} 3 \mathrm{O}-\mathrm{I}, 400^{\circ} \mathrm{F}\right.$.), showed a uniformly high impact resistance and the fifth, $760-800^{\circ} \mathrm{C}$. $\left(\mathrm{I}, 400-\mathrm{I}, 470^{\circ} \mathrm{F}\right.$.), produced a decided drop in this property of the iron, as is to be expected.

These results have some very interesting aspects. The major embrittlement was evidently confined to a definite range of quenching temperatures, with a rapid rise in the resistance of the material to impact on either side of this zone. The recovery on the high-temperature side was quite remarkable, as the iron not only regained its original impact resistance but registered a pronounced improvement over this value. When quenched from $545^{\circ} \mathrm{C}$. (I,OI $5^{\circ} \mathrm{F}$.), for instance, it took only one-seventh the energy to break the specimen as to fracture it in the untreated condition. But on quenching from only a slightly higher temperature, $610^{\circ} \mathrm{C}$. $\left(\mathrm{I}, \mathrm{I} 30^{\circ} \mathrm{F}\right.$.), the energy required was $\mathrm{I} / 2$ times that for the untreated metal and I I times that of the brittle iron. This exceptional effect dropped off but little. as the quenching temperature was raised even to the critical point, about $760^{\circ} \mathrm{C}$. $\left(\mathrm{I}, 400^{\circ} \mathrm{F}\right.$.). Still higher temperatures, up to $800^{\circ} \mathrm{C}$. $\left(\mathrm{I}, 470^{\circ} \mathrm{F}\right.$.), caused a more decided drop in impact resistance.

It was surprising to find the embrittlement zone limited by such definite boundaries. The transition ranges were unexpectedly narrow. Unfortunately, however, the region of greatest deterioration included those temperatures that are practical for hot-dip galvanizing. The limitations of this embrittlement region were, therefore, not such that the danger zone could be avoided by changing the galvanizing temperature.

It is interesting to note that specimens 249 and 250 were heated above the critical range without making the metal very brittle. The microscope showed, however, that only a small amount of carbon had gone back into solution at the grain boundaries in this case. A slightly longer time or higher temperature would have increased the deterioration greatly.

The above results on the investigation of the variation of impact resistance with quenching temperature were so novel and interesting that it seemed advisable to repeat this work on two 
other types of malleable iron. The composition of all three kinds of iron in the annealed condition is given in Table 6 . These three series of samples were each cast in different foundries so that their thermal histories also varied. Type A metal is the one on which the work described above was performed. Table 7 and Figure 2, curves $B$ and $C$, show the results obtained with the two supplementary series of samples.

TABLE 6.-Malleable-Iron Compositions. ${ }^{1}$

\begin{tabular}{|c|c|c|c|c|c|c|c|}
\hline \multirow[b]{2}{*}{ Type. } & \multicolumn{6}{|c|}{ Composition. } & \multirow{2}{*}{$\begin{array}{c}\text { Energy } \\
\text { absorbed } \\
\text { in impact } \\
\text { test. }\end{array}$} \\
\hline & Total C. & $\begin{array}{c}\text { Graphitic } \\
\text { C. }\end{array}$ & $\mathrm{Si}$ & $\mathbf{P}$ & $\mathbf{M n}$ & $\mathbf{s}$ & \\
\hline $\begin{array}{l}\mathrm{A} \\
\mathrm{B} \\
\mathrm{B} \\
\mathrm{C}\end{array}$ & $\begin{array}{l}2.10 \\
2.35 \\
2.90\end{array}$ & $\begin{array}{l}2.00 \\
2.10 \\
2.83\end{array}$ & $\begin{array}{r}0.80 \\
.91 \\
.64\end{array}$ & $\begin{array}{r}0.20 \\
.18 \\
.17\end{array}$ & $\begin{array}{r}0.26 \\
.25 \\
.38\end{array}$ & $\begin{array}{r}0.073 \\
.051 \\
.072\end{array}$ & $\begin{array}{r}\text { Ft.-1bs. } \\
7.2 \\
5.7 \\
5.6\end{array}$ \\
\hline
\end{tabular}

3 Analyses by H. A. Bright, associate chemist, Bureau of Standards.

TABLE 7.-Variation of Impact Value With Quenching Temperature.

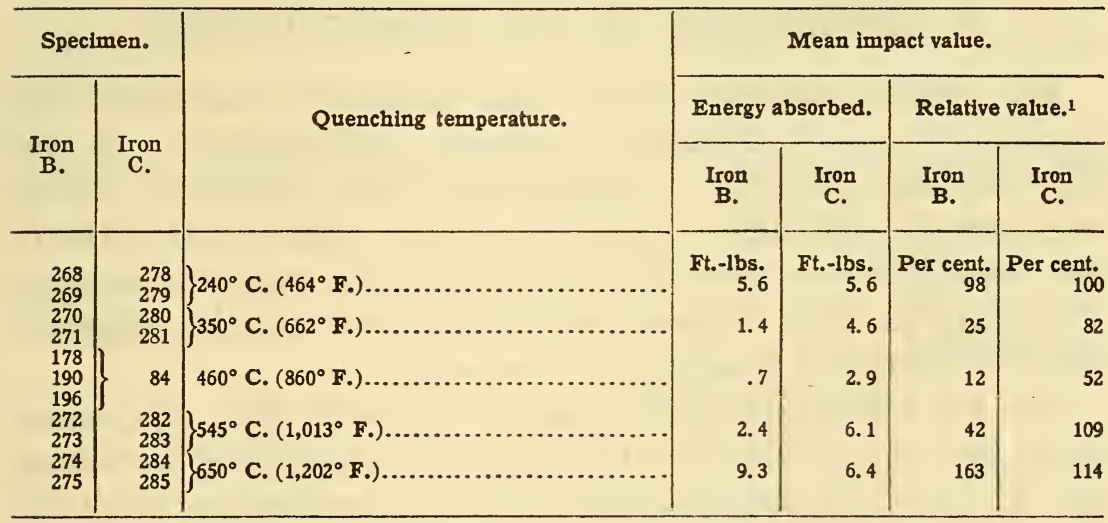

1 As compared with the untreated material.

Although there were not as many points determined in the later cases, it is evident that the same type of curve holds for all three metals (see fig. 2). The range of impact values was much less for the $\mathrm{C}$ iron than for the others, since it did not become so brittle at $460^{\circ} \mathrm{C}$. $\left(860^{\circ} \mathrm{F}\right.$.) nor recover at $650^{\circ} \mathrm{C}$. $\left(\mathrm{I}, 200^{\circ} \mathrm{F}\right.$.) to the degree the $\mathrm{A}$ and $\mathrm{B}$ irons did. The $\mathrm{B}$ iron, and more particularly the $\mathrm{C}$ iron, started to embrittle at a higher and to recover its normal properties at a lower temperature than $\mathrm{A}$ iron. The brittleness range for the $\mathrm{B}$ and $\mathrm{C}$ irons was, therefore, nar- 
rower than that for the $\mathrm{A}$ iron. It is significant, however, that the mean of the temperatures that caused low-impact values was approximately the same in every case.

It may be well to summarize the effects, some of them rather striking, produced by varying the quenching temperature. First, there was a clearly defined range in which the malleable iron exhibited its maximum embrittlement. This zone approximated the brittleness range ${ }^{5}$ described by Guillet and Revillon for steel. Second, the magnitude of the zone of deterioration varied considerably in different kinds of malleable iron, but the mean temperature of this range appeared to be about the same in every case, namely, about $45^{\circ} \mathrm{C}$. $\left(840^{\circ} \mathrm{F}\right.$.). Third, quenching from temperatures above the embrittlement zone and below the critical point yielded iron that was even more resistant to impact than the untreated metal. Fourth, after the critical temperature had been passed the impact resistance rapidly decreased. Variation of the quenching temperature was capable of producing remarkable effects.

\section{ELIMINATION OF THE EMBRITTLEMENT.}

The results recorded above had definitely established the importance of heat treatment in causing embrittlement. It was only natural, therefore, to expect that heat treatment should overcome the difficulty. It has been shown that on both sides of the embrittlement zone the iron had good impact resistance. Treatment in either of these two regions, consequently, suggested itself for the rôle of benefactor to the metal.

The low-temperature side was investigated first. Specimens of the type $\mathrm{A}$ iron were first made brittle by quenching them from $460^{\circ} \mathrm{C}$. $\left(860^{\circ} \mathrm{F}\right.$.) and were then treated in an electric oven for a time. Samples that were embrittled and then heated at $200^{\circ} \mathrm{C}$. $\left(390^{\circ} \mathrm{F}\right.$.) for four hours showed some improvement. In fact, after this low-temperature anneal the metal had regained approximately I5 per cent of its original impact resistance. It was evident, therefore, that such treatment would improve the metal. On the other hand, it was doubtful if the original shock resistance could be restored in this way, since equilibrium conditions would be very slowly reached at these low temperatures. Yet raising the temperature of treatment very much would bring it within the region of deterioration. 
Similar experiments were tried on the high-temperature side of the embrittlement zone. A specimen was given the embrittlement treatment, then reheated to $615^{\circ} \mathrm{C}$. $\left(\mathrm{I}, \mathrm{I} 40^{\circ} \mathrm{F}\right.$.) and again quenched. The impact value of the resulting metal was II.I foot-pounds, or 154 per cent of that of the untreated iron, which was a highly gratifying result as it showed that the effect of the embrittling treatment had apparently been entirely effaced. (See Table 8.)

A method was thus at hand for reclaiming castings made defective by the galvanizing treatment at the expense, however, of spoiling the zinc coating. A still more desirable step would be made if assurance could be given that the malleable iron would not deteriorate in the first place. The manufacturer wants a product he can hot dip with impunity. With this thought in mind, specimens were quenched from $615^{\circ} \mathrm{C} .\left(\mathrm{I}, \mathrm{I} 40^{\circ} \mathrm{F}\right.$.) and then given the embrittling treatment; that is, heated to $460^{\circ} \mathrm{C}$. $\left(860^{\circ}\right.$ F.) and quenched. As shown by Table 8 , the results evidenced a high shock resistance. In fact, such a sample held at $460^{\circ} \mathrm{C}$. $\left(860^{\circ} \mathrm{F}\right.$.) for half an hour before quenching still had a high impact value. Such data indicated that the question of overcoming the tendency to deteriorate had been satisfactorily answered.

TABLE 8.-The Effect of Quenching From $615^{\circ}$ C. $\left(1,140^{\circ}\right.$ F. $)$ on the Embrittlement of Iron A.

\begin{tabular}{|c|c|c|c|}
\hline \multirow{2}{*}{$\begin{array}{l}\text { Specimen } \\
\text { number. }\end{array}$} & \multirow{2}{*}{ Treatment. } & \multicolumn{2}{|c|}{ Mean impact value. } \\
\hline & & $\begin{array}{c}\text { Energy } \\
\text { absorbed. }\end{array}$ & $\begin{array}{l}\text { Relative } \\
\text { value. }\end{array}$ \\
\hline $241 \ldots$ & 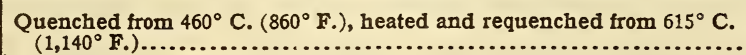 & Ft.-lbs. & $\begin{array}{r}\text { Per cent. } \\
154\end{array}$ \\
\hline $\begin{array}{ll}253 \ldots \\
257 \ldots\end{array}$ & 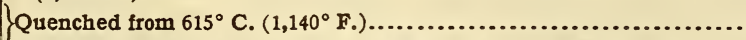 & 10.8 & 150 \\
\hline $254:-$ & Quenched from $615^{\circ} \mathrm{C} .\left(1,140^{\circ} \mathrm{F}.\right)$, heated and requenched from $460^{\circ} \mathrm{C}$. & 100 & \\
\hline $256 . .$. & 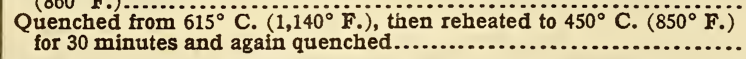 & $\begin{array}{r}10.0 \\
8.9\end{array}$ & 124 \\
\hline
\end{tabular}

1 As compared with the untreated material.

Since it had been found that the effect of heat treatment varied with different kinds of malleable iron (see Table 7), it next became necessary to see if this relatively high-temperature treatment could be depended upon to eliminate the galvanizing deterioration in general. One sample of each of the $\mathrm{B}$ and $\mathrm{C}$ metals described above was heated to $655^{\circ} \mathrm{C}$. ( $1,210^{\circ} \mathrm{F}$.), quenched and then given the embrittling treatment. The impact resistance of the $\mathrm{B}$ specimen was IO.I foot-poinds (relative value $\mathrm{I} 77$ per cent) and that 
of the C sample 6.9 foot-pounds (I23 per cent). The results on the $\mathrm{A}$ iron were thus corroborated.

In order to secure still more data on the feasibility of using this high-temperature quench as a general remedy for deterioration in galvanizing, specimens from 47 different heats of malleable iron were treated and tested. A comparison was made between three types of samples, $(a)$ untreated, $(b)$ embrittled, and $(c)$ quenched from $650^{\circ} \mathrm{C}$. $\left(\mathrm{I}, 200^{\circ} \mathrm{F}\right.$.) then given the embrittling treatment. The carbon content of this metal varied from 2.6 to 3.0 per cent and the silicon from 0.45 to 0.95 per cent. Most of this material was, therefore, relatively high-carbon, low-silicon malleable iron. On quenching from $460^{\circ} \mathrm{C}$. $\left(860^{\circ} \mathrm{F}\right.$.) the resulting impact resistance varied from 9 to 84 per cent (average 59 per cent) of that of the original metal. A similar treatment, preceded by quenching in water from $650^{\circ} \mathrm{C}$. $\left(\mathrm{I}, 200^{\circ} \mathrm{F}\right.$.), yielded metal whose resistance to impact ranged from 88 to 122 per cent (average Io3 per cent) of that of the initial stock. Although the high-temperature treatment did not produce as marked an improvement in this case as previously met with, still the metal thus treated was decidedly better than the untreated iron. In every instance the embrittlement had been either almost or entirely eliminated.

In order to show definitely that the high-temperature treatment would overcome the deterioration due to galvanizing, specimens of $\mathrm{A}$ iron quenched from $650^{\circ} \mathrm{C}$. $\left(\mathrm{I}, 200^{\circ} \mathrm{F}\right.$.) were hot dipped and then tested in impact. Similar samples, untreated, were also run at the same time for comparison. After galvanizing, the untreated samples gave an impact resistance of 0.9 foot-pound, which was only i 2 per cent of the value of the specimen before treatment, while those quenched from $650^{\circ} \mathrm{C}$. $\left(\mathrm{I}, 200^{\circ} \mathrm{F}\right.$.) gave far higher values, namely, II.5 foot-pounds (relative value I6o per cent).

The tensile properties of malleable iron in the two conditions(a) untreated and (b) quenched from $650^{\circ} \mathrm{C}$. ( $\left(\mathrm{I}, 200^{\circ} \mathrm{F}\right.$.) -was also compared. Five of the usual A. S. T. M. malleable iron test bars, type $\mathrm{C}$ iron, were tested in each of these two conditions. Table 9 lists the results.

TABLE 9.-Tensile Properties of Untreated and Treated Malleable Iron.

\begin{tabular}{|c|c|c|c|c|}
\hline Type. & $\begin{array}{l}\text { Propor- } \\
\text { tionallimit. }\end{array}$ & Yield point. & $\begin{array}{l}\text { Ultimate } \\
\text { strength. }\end{array}$ & Elongation. \\
\hline 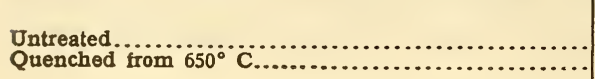 & $\begin{array}{r}\text { Lbs./in. }{ }^{2} \\
15,900 \\
16,800\end{array}$ & $\begin{array}{r}\text { Lbs./in. }{ }^{2} \\
32,500 \\
35,900\end{array}$ & $\begin{array}{r}\text { Lbs./in. }{ }^{2} \\
50,500 \\
51,000\end{array}$ & $\begin{array}{r}\text { Per cent. } \\
10.5 \\
10.5\end{array}$ \\
\hline
\end{tabular}


These data show that the tensile properties of the heat-treated bars were as good and perhaps a little better than those of the untreated samples. The effect of the relatively high-temperature treatment seems to have been entirely beneficial to the iron.

It has been demonstrated, therefore, that not only was there a heat-treatment zone between the deterioration range and the critical point in which a beneficial influence was exerted on malleable iron, but this improvement in quality was retained even after subsequent galvanizing. The magnitude of this effect varied from one heat of malleable iron to another, but in every case the improvement was pronounced. In fact, the galvanizing embrittlement was eliminated without injuring the other physical properties of the iron.

\section{DISCUSSION.}

The results presented above are not offered as a solution of the problem of the embrittlement of malleable iron in hot-dip galvanizing, although a method of overcoming this fault is presented. The object of the paper is rather to list the pertinent information obtained in a study of this practical and perplexing difficulty by correlating the observations in an effort to clear up the uncertainties of the subject as much as possible.

As has been mentioned, an interesting parallel was found between the temperatures at which galvanizing deterioration takes place and those recognized as the blue-brittleness range of lowcarbon steel. The distinction must be borne in mind that the failure in the latter case occurs while the metal is still at the elevated temperature. The suggestion is offered, however, that the galvanizing embrittlement may be an exaggerated form of blue brittleness that is retained at ordinary temperatures by quenching. If such is the case, a further examination of the cause of hot-dip deterioration affords a convenient means of attack on the more general problem. Since no impact tests were made on malleable iron at other than room temperature, the relationship of the two phenomena must remain for the present an interesting conjecture.

The very definite manner in which the embrittlement zone is limited (see fig. 2) is surprising. In fact, the transitions are so abrupt as to intimate the possible existence of transformations at these points. Some evidence in support of this surmise was furnished by thermal curves obtained on certain samples of malleable 
iron. The whole matter needs much more study, however, before any well-founded theory can be offered to explain the facts.

A novel feature of the results lies in the fact that quenching from temperatures above the embrittlement zone and below the critical point yields malleable iron of superior quality. It seems almost paradoxical that the physical properties of such well-annealed material should be improved by reheating to dull redness and quenching. Experience has, however, since amply demonstrated the truth of this generalization for malleable iron.

Not the least important of the results has been the demonstration that the effects of such thermal manipulations as were performed in this investigation can be conveniently and quantitatively measured by means of the notched-bar impact test. Several hundred specimens were tested in this way with entirely consistent results. Moreover, samples of the same metal, heat treated in the same way, but on different occasions always checked with fair precision.

The marked effects produced by thermal treatments have been noted. Yet it must be admitted that the mechanism of these changes is still unknown. The phosphorus content undoubtedly is of importance in this connection, but the question of the process by which this impurity exerts this influence can not be answered at present. Other factors than phosphorus have an important bearing on the problem and in this connection the thermal history of the metal is pertinent. In any further investigation of the problem the effect of variations in the annealing or graphitizing treatment must be given close consideration.

\section{SUMMARY.}

Numerous tests on samples of commercial malleable iron, mostly impact tests on specimens heat treated at relatively low temperatures, have been recorded here. A consideration of the data thus presented brings out the following facts:

I. The embrittlement of malleable iron sometimes noted in hot-dip galvanizing is due chiefly to the incidental heat treatment.

2. The notched-bar impact test forms a convenient means of measuring such deterioration.

3. Quenching malleable iron from temperatures between 400 and $500^{\circ} \mathrm{C}$. ( 750 and $930^{\circ} \mathrm{F}$.) makes it brittle to a greater or lesser degree depending on the iron. The rate of heating and the time the metal is held at this temperature exert but little influence. 
Aging after treatment has no apparent effect. On the other hand, substituting slower rates of cooling for the quenching treatment produces a metal of higher impact resistance.

4. Heating to $650^{\circ} \mathrm{C}$. $\left(\mathrm{I}, 200^{\circ} \mathrm{F}\right.$.) for a few minutes followed by quenching (in water at room temperature) eliminates the embrittlement, even if the metal is subsequently galvanized.

5. Further investigation will be required to determine the fundamental cause of the behavior observed.

The author takes this occasion to express his appreciation of the aid and cooperation extended to him by many members of the bureau staff, especially $\mathrm{H}$. S. Rawdon and other members of the division of metallurgy. Credit is also due the Ohio Brass Co., whose active interest and assistance in the problem made this work possible.

Washington, August II, I923. 